\title{
Relationship between Treasury bill rate and NEPSE index in Nepal
}

\author{
Rajesh Gurung, MPhil \\ Lecturer, Nepal Commerce Campus, T.U.
}

\begin{abstract}
This study has examined the relationship between 91-days Treasury bill rate and NEPSE Index with the use of annual time series data taken from Mid-July 1994 to Mid-July 2018 in the context of Nepal. Time series are stationary at first differenced and they are cointegrated in order 1, i.e., I (1). Error Correction Model (ECM) confirms the long-run causality from 91-days Treasury bill rate (INT) to NEPSE Index (IND) at 5 percent level and long-run causality from IND to INT at 10 percent level. This bi-directional causality implies that the interest rate policy of Nepal Rastra Bank considerably influences in the stock market performances in long-run as well as the investors' decisions in choices between stock market and bank deposits. This finding justifies the theoretical underpinning of impact of cost of capital in business investment decisions and demand for and supply of securities in capital markets. However, Wald statistics for joint short-term coefficients of variables under the interest does not support for shortrun causality between them. This finding justifies the theoretical underpinning that low cost of capital crucially linked to create the demand for and supply of securities through business investment opportunities. Higher interest rate, in other hand, not only discourage the businesses to use credit but also stimulate investors to switch to bank deposits causing decline in stock prices.
\end{abstract}

Key words: Treasury bills rate, NEPSE index, Cointegration, Error correction model

\section{Introduction}

The study of relationship between the interest rate and the performance of stock market has received considerable attention in both theory amongst academicians, students, researchers, regulators, policymakers, and other market participants as the interest rate has important implication that influences investment decisions through the implementation of monetary policy by the central bank of a country. In a developed economy, the stock market index is considered as a mirror image of economy. The growing stock market index indicates the investors' confidence over the good future prospects of economy. The interest rate has been considered as an important factor amongst the many forces influencing the stock market performance. Theoretically, interest rate and stock market performance has negative relationship. When the banking institutions offers higher interest rates in bank deposits, stock markets become less attractive to investors and they switch their money from stock market into bank that causes to decline in stock prices from higher stock selling in market. Moreover, higher bank deposit increases cost of credit and discourage to business investment in the economy to decrease demand of securities. Ibrahim and Musah (2014) argue that a rise in interest rate will lead to a higher borrowing costs, lower future profits, increase in discount rate for equity investors; and then cause to decline stock prices. The increase in interest rates, thus, has indirect 
Silver Jubilee Issue - 2019

impact on stock prices.

Fama (1960) introduced the well-established view of efficiency in operating securities markets and argued that securities prices immediately reflect the information that available. Rose (1976), in Arbitrage Pricing Theory, introduced multifactor forces to develop linkage between stock returns and other variables like interest rate structure, risk premium, inflation, and level of industrial production. Many other studies (for example; Mayasmi, et al. (2004), Rashid (2008), Hunjra, et al. (2014)) have documented impact of macroeconomic fundamentals on stock prices. In addition to the macro-eoconomic fundamentals, stock market performances are also affected by other variables such as mood of society, political, social, and other events (Issahaku, et al. (2013), Beaulieu et al. (2006), Schmith (2005), Dongol (2010), Shrestha and Subedi (2014)).

Theoretical literature and empirical studies have documented existence of relationship between the interest rates and performance of stock market around the world, however, their presence and nature of relationship seems to vary from one country to others. Wongbampo and Sharma (2002) examined the association between the stock market behavior and macroeconomic fundamentals and documented a negative relationship between interest rates and stock prices for Singapore, Thailand, and Philippines, but positively related to Malaysia and Indonesia. A negative association between Treasury bill rate and index has also been reported in other studies such as; Ochieng \& Oriwo (2012), Khan et al. (2014), Ibrahim and Musah (2014), etc.

Rashid (2008) examines the dynamic interactions between stock prices and four macro-economic variables in Pakistan, using Granger causality and co-integration tests. It was discovered that there is a longrun bi-directional causation between the stock prices and interest rates. The result also reveals that there is a long-run Granger caused by changes in interest rates in the short-run. Bahman, et al. (2009) studied the association between stock prices and selected macro-economic variables in Malaysia. They employed VECM/VAR framework. They showed that interest rate was positively related to Malaysian stock market return in the long-run. Their causality test signifies a bi-directional relationship between interest rates and stock market return. A positive relationship between stock prices and the treasury bill rate also reported in Kenya (Mutuku and Ng'eny (2015)). Xiufang (2010) found that there is a unidirectional relationship exists between the interest rate and stock prices, through the direction from stock prices to the interest rate.

The study results of relationship between the interest rate and stock market in South Asian countries are not consistent. For example, Naik (2013) investigated the shock of macroeconomic variables on the stock market behavior in India. He revealed that the interest rate and exchange rae were found to be insignificant relationship with stock market index. Uddin and Alam (2007) examines the linear relationship between share price and interest rate, share price and changes of interest rate, changes of share price and interest rate, and changes of share price and changes of interest rate on Dhaka Stock Exchange (DSE). For all of the cases, included and excluded outlier, it was found that interest rate has significant negative relationship with share price and changes of interest rate has significant negative relationship with changes of share price.

The empirical evidences, however, present inconclusive results regarding the relationship between the interest rates and performance of the stock market around the world. This study attempts to establish the relationship between the interest rate measured by 91-days Treasury bill rates and stock market performance measured with NEPSE Index using the time series data in Nepalese context.

\section{Research Methodology}

This study has employed various econometrics tests: Augmented Dickey Fuller (ADF) Tests in addition to Philip-Perron (PP) Tests to confirm time series stationary, Johansen Test of Co-integration to examine the possibility of long-run relationship between variables, and the causality tests to develop causal relationship between the time series variables.

Granger \& Newbold (1974) suggest that the use of non-stationary time series (unit root) data in regression analysis provides spurious regression. Thus, the stationary in time series data is precondition in 
developing the long-run relationship among the variables of interest. The unit root has been tested with the help Augmented Dickey Fuller (ADF) prescribed by Dickey and Fuller (1979), presented in equation 2.1. The null hypothesis of time series has got unit root, i.e. $\beta=0$ is tested against alternative hypothesis of time series has not unit root, i.e. $\beta \square 0$.

$\Delta \mathrm{yt}=\alpha+\beta \mathrm{yt}-1+=1 \mathrm{p} \lambda \mathrm{i} \Delta \mathrm{yt}-1+\square \mathrm{t}$

$\alpha, \beta$, and $\lambda$ represent the parameters, $\varepsilon$ is the white noise, and $\mathrm{y}$ is the time series.

The optimal number of lag has been selected using the various criteria: Sequential modified LR test statistics (LR), Final Prediction Error (PPE), AkaikeInformation Criterion (AIC), Schwarz Information Criterion (SC), Hannan-Quinn Information Criterion (HQ). Lower values from respective criteria suggest optimal lag for better time series model. Johansen (1988) procedures has been employed to confirm the cointegration between the variables and time series are said to be nonintegrated if they have long-run association. Cointegration test in Johansen (19880 procedures describestwo likelihood ratios: trace test and eigen value test as described in equation 2.2 and equation 2.3 .

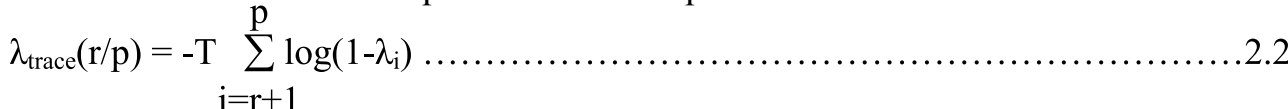

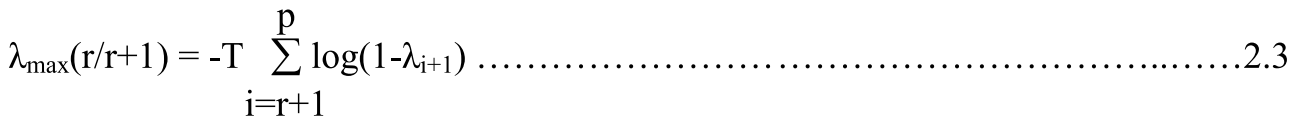

Where, $r$ refers to $0,1,2, \ldots . . p-1 ; T$ is the number of useable observations; $\lambda i$ and $\lambda i+1$ represent the estimated value of the characteristics roots. The null hypothesis of there is no cointegrating vector against there is one or more cointegrating vectors is tested.

If non-stationary time series becomes stationary after the first difference i.e., I(1) and they are cointegrated, Vector Error Correction Model (VECM) can be proceed to examine short run as well as longrun dynamics of cointegrated series as given in equation 2.4 .

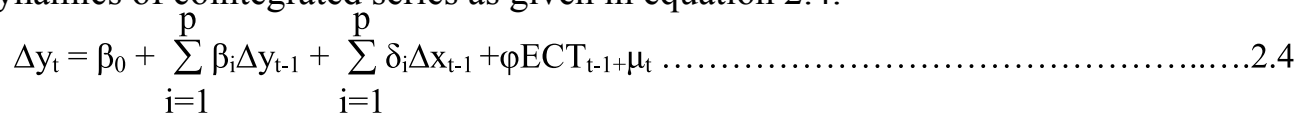

In traditional VECM equation 2.4, the changes in variable ' $y$ ' are the function of previous changes in variable ' $y$ ' and variable ' $x$ '. 'ECT' in the equation is error correction term and is the OLS residuals from the long-run cointegrating regressions from the equation 2.5. The coefficient of ECT, $\varphi$, is the speed of adjustment, because it measures the speed at which ' $y$ ' returns to equilibrium after a change in ' $x$ '.

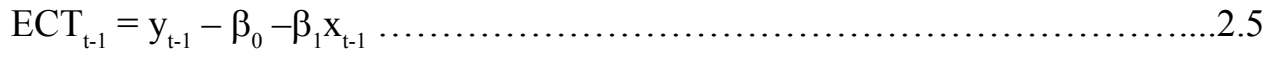

\section{Econometric Results}

\section{Results of Unit Root Test}

The results ADF test, in addition to Philips-Perron (PP) test proposed by Philips and Perron (1988), for unit root have been reported in Table 3.1. The times series of NEPSE Index (IND) and T-bill interest rate (INT) are non-stationary at level but exhibit stationary at first difference in the both tests. This confirms the time series of IND and INT time series are integrated in order 1,I(1). 
Silver Jubilee Issue - 2019

Table 1

Unit Root Test

\begin{tabular}{lccccc}
\hline \multirow{2}{*}{ Variables } & \multicolumn{2}{c}{ Test Statistics } & \multirow{2}{*}{ Adj R } & DW & $\begin{array}{c}\text { Order of } \\
\text { Integration }\end{array}$ \\
\cline { 2 - 3 } & ADF Test & P-P Test & & & I(1) \\
IND & $-4.2084\left(0.0036^{*}\right)$ & $-4.2074\left(0.0036^{*}\right)$ & 0.4316 & 1.8749 & I(1) \\
INT & $-4.1051(0.0045)$ & $-4.0291(0.0054)$ & 0.4188 & 1.8365 & \\
\hline
\end{tabular}

Figure in parenthesis is p-values and * indicates significant at 1 percent level

The Figure 1(a) and Figure 1 (b) present graphic presentation of T-bill interest rate (INT) and NEPSE Index (IND) at level and first difference respectively.

Figure 1 (a): IND and INT at Level Form


Figure 1 (b): IND and INT at First Difference
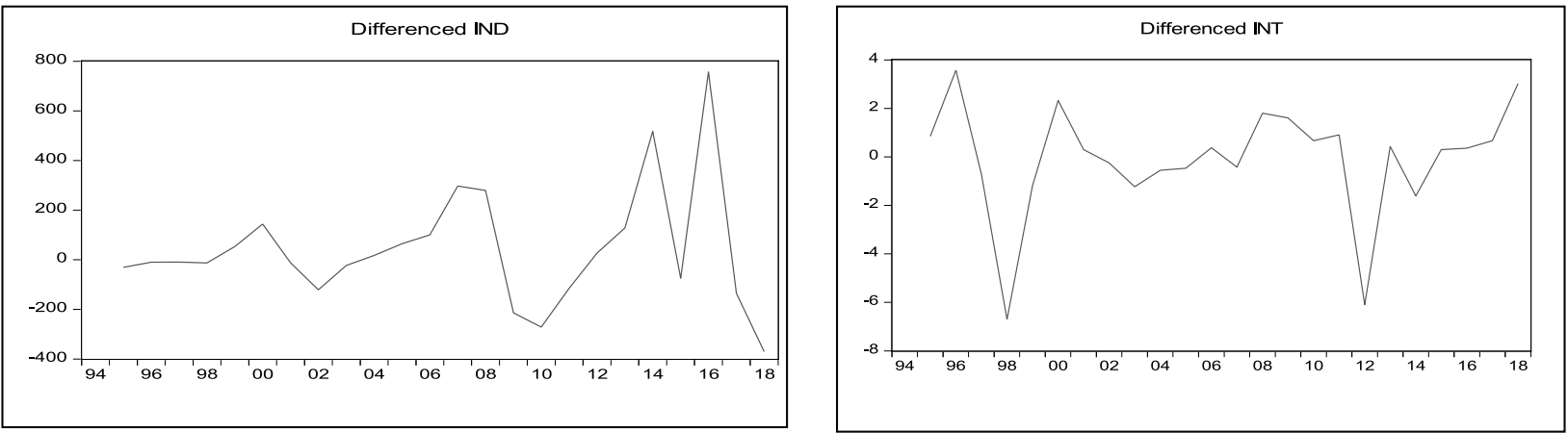

\section{Results of Johansen Test of Cointegration}

Before beginning the Johansen Test of Cointegration, the optimal lag length (p) has been determined using lag length selection criteria: Sequential modified LR test statistics (LR), Final Prediction Error (PPE), AkaikeIinformationCriterion (AIC), Schwarz Information Criterion (SC), and Hannan-Quinn Information Criterion (HQ). All these criteria suggest the optimal lag length equal 1. Johansen Test of Cointegration has been performed to ensure long-run association between the T-bill rate and NEPSE Index, and results have been reported in Table 2 .

Table 2

Johansen Test of Cointegration

\begin{tabular}{lccccc}
\hline $\begin{array}{c}\text { Hypothesized No. } \\
\text { of CE(s) }\end{array}$ & Eigenvalue & Trace Statistics & Max-Eigen Statistics & $\begin{array}{c}\text { No. of CE } \\
(\mathrm{s})\end{array}$ & Lags \\
\hline None* & 0.4767 & $18.3311\left(0.0182^{* *}\right)$ & $14.8979\left(0.0397^{* *}\right)$ & 1 & 1 \\
At most 1 & 0.1387 & $3.4332(0.0639)$ & $3.4332(0.0639)$ & 1 & \\
\hline
\end{tabular}

** indicates $\mathrm{p}$-values and significant at 5 percent level 
The null hypothesis of no integrating equations (none) is tested against the alternative hypothesis of cointegration between each pair of variable: IND and INT. The test statistics suggest that the null hypothesis of no integrating equation(s) is rejected and both the trace test and max eigen value statistics indicate the 1 cointegrating equation at 5 percent level. This confirms existence of long-run relationship between the Treasury bill rate (INT) and NEPSE Index.

\section{Results of Error Correction Model (ECM)}

As the first differenced time series are cointegrated, error correction model (ECM) is employed to examine short run as well as long-run dynamics of cointegrated time series. Table 3 reports the results of ECM with NEPSE Index (IND) as dependent variable. The coefficient of error term (ECT) satisfies the both the conditions of negative values of coefficient (- 0.1874) and it is significant at 5 percent level. This negative coefficient indicates that the departure in one direction from equilibrium, the correction would be pulled back to other direction in the next period, which is by 18.74 percent, so as to ensure equilibrium. It confirms existence of long-run causality running from INT to IND. The serial correlation LM test and Jarque-Bera normality test confirms the residuals with no serial correlation and are normally distributed.

Table 3

Error Correction (ECM), IND (dependent variable)

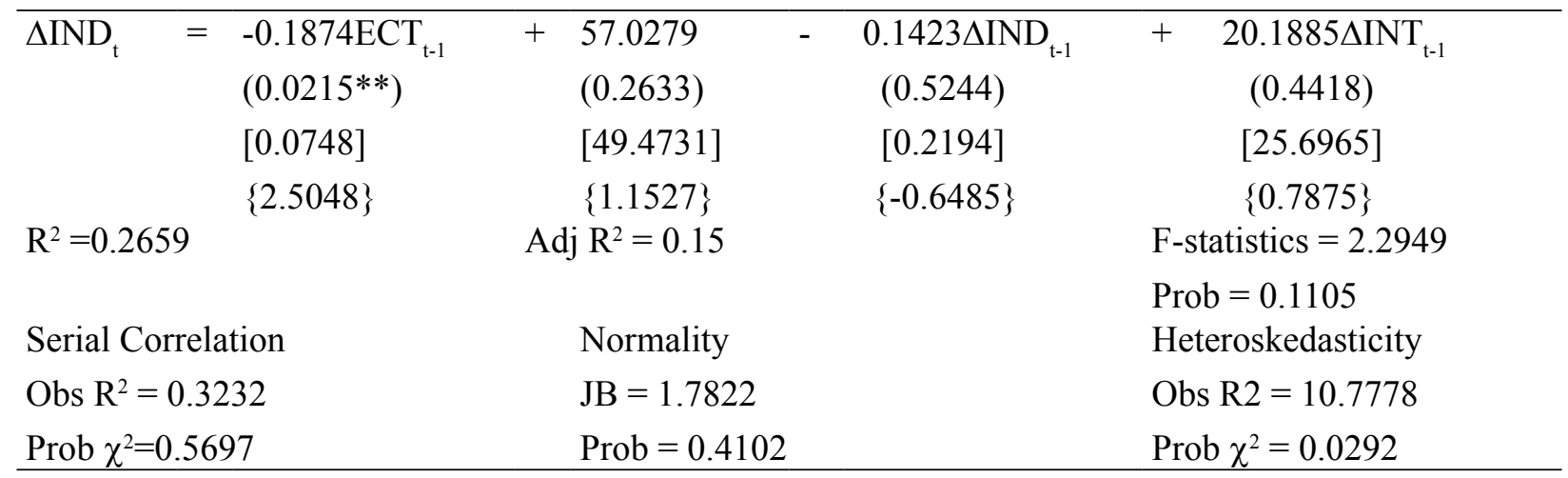

Figures in ( ), [ ], and \{\} are p-values, standard errors, and t-statistics

*** indicates significant at 10 percent level

Table 4 reports the error correction model (ECM) with T-bill interest rate (INT) as a dependent variable. The coefficient of ECT is negative (-0.4824) and it is significant at 10 percent level. This implies weak evidence of NEPSE Index causing to T-bill interest rate. The residual diagnostic confirms that the residuals are free from the problems of serial correlation, residuals are normally distributed, and no problems of heteroskedasticity.

Table 4

Error Correction Model (ECM), IND (dependent variable)

\begin{tabular}{|c|c|c|c|c|c|}
\hline \multirow[t]{2}{*}{$\Delta \mathrm{INT}_{\mathrm{t}}$} & $\begin{aligned}= & -0.4824 \mathrm{ECT}_{\mathrm{t}-1} \\
& (0.0624 * * *)\end{aligned}$ & $\begin{aligned}+ & 0.0003 \Delta \mathrm{IND}_{\mathrm{t}-1} \\
& (0.8807)\end{aligned}$ & + & $\begin{array}{l}0.3699 \Delta \mathrm{INT}_{\mathrm{t}-1} \\
(0.1716)\end{array}$ & $\begin{array}{l}0.0636 \\
(0.9003)\end{array}$ \\
\hline & {$[0.2437]$} & {$[0.0022]$} & & {$[0.2604]$} & {$[0.5014]$} \\
\hline \multirow{2}{*}{\multicolumn{2}{|c|}{$\mathrm{R}^{2}=0.1979$}} & $\begin{array}{c}\{0.1521\} \\
\text { Adj } R^{2}=0.066\end{array}$ & & $\begin{array}{l}\{1.4207\} \\
\text { F-statistics }=1.5219\end{array}$ & $\{-0.1269\}$ \\
\hline & & & & $(0.2411)$ & \\
\hline \multicolumn{2}{|c|}{ Serial Correlation } & Normality & & Heteroskedasticity & \\
\hline \multicolumn{2}{|c|}{ Obs $R^{2}=1.7994$} & $\mathrm{JB}=0.5605$ & & Obs $R^{2}=5.9285$ & \\
\hline \multicolumn{2}{|c|}{ Prob $\chi^{2}=0.1798$} & Prob $=0.7556$ & & Prob $\chi^{2}=0.2045$ & \\
\hline
\end{tabular}

Figure in ( ), [ ], and \{ $\}$ are $p$-values, standard errors, and t-statistics

*** indicates significant at 10 percent level 
The Wald Test statistics for joint short-term coefficients of NEPSE Index and T-bill interest rate have been performed with to ensure whether short-run relationships between these variables exist. The first null hypothesis of IND does not cause INT and second hypothesis of INT does not cause IND, both of these hypotheses were rejected at 5 percent level. This implies that neither the NEPSE Index nor the T-bill interest rate can cause one another in short-run. The results of Wald statistics and diagnostic checks of residuals have been reported in Table 5 .

Table 5

Vector Autoregressive (VAR) for IND and INT

\begin{tabular}{|c|c|c|}
\hline \multirow{3}{*}{ H0: IND does not cause INT } & \multicolumn{2}{|c|}{ Wald Test } \\
\hline & Chi-Sq & $\mathrm{P}$-value \\
\hline & 0.0231 & 0.8791 \\
\hline Serial Correlation & Normality & Heteroskedasticity \\
\hline Obs R2 $=1.7994$ & $\mathrm{JB}=0.5605$ & Obs $\mathrm{R}^{2}=5.9286$ \\
\hline Prob $\chi 2=0.1798$ & Prob $=0.7556$ & Prob $\chi^{2}=0.2045$ \\
\hline \multirow{3}{*}{ H0: INT does not cause IND } & \multicolumn{2}{|c|}{ Wald Test } \\
\hline & Chi-Sq & P-value \\
\hline & 0.6172 & 0.4321 \\
\hline Serial Correlation & Normality & Heteroskedasticity \\
\hline Obs $\mathrm{R}^{2}=0.3232$ & $\mathrm{JB}=1.7822$ & Obs $\mathrm{R}^{2}=10.7778$ \\
\hline Prob $\chi^{2}=0.5697$ & Prob $=0.4101$ & Prob $\chi^{2}=0.0292$ \\
\hline
\end{tabular}

\section{Conclusion}

This study has examined the relationship between 91-days Treasury bill rate and NEPSE Index with the use of annual time series data taken from Mid-July 1994 to Mid-July 2018 in the context of Nepal. Time series are stationary at first differenced and they are cointegrated in order 1, i.e., I (1). The coefficient of error correction term in Error Correction Model (ECM) is negative and significant at 5 percent level that confirms the long-run causality from 91-days Treasury bill rate (INT) to NEPSE Index (IND). Likewise, the error correction term is negative and significant at 10 percent level which implies long-run causality from IND to INT. The bi-directional causality between the interest rate and stock index has an important implication that it not only the interest rate policy of Nepal Rastra Bank considerably influences in the stock market performances in long-run but also the stock market performances cause the investors in their decision to choose between stock market and bank deposits. This finding also justifies the theoretical underpinning that low cost of capital crucially linked to create the demand for and supply of securities through business investment opportunities. Higher interest rate, in other hand, not only discourage the businesses to use credit but also motivate investors to switch to bank deposits causing decline in stock prices. However, the Wald Test for joint short-term coefficients of variables does not support for short-run causality between the Treasury bill rate and NEPSE Index in Nepal.

\section{References}

Beaulieu, M. C., Cosset, J. C., \&Essaddam, N. (2006). Political uncertainty and stock market returns: evidence from the 1995 Quebec Referendum. Canadian Journal of Economic, 39 (2), 621-641.

Boudoukh, J., Feldman, R., Kogan, S, and Richardson, M. (2013). Which news moves stock prices? A textual analysis. NBER Working Paper, No. 18725

Dickey, D. A. \& Fuller, W. A. (1979). Distribution of the estimators for autoregressive time series with a unit root. Journal of the American Statistical Association, 14(366), 427-431.

Dongol, J. (2010). Testing random-walk behavior in Nepalese stock market. PYC Nepal Journal of 
Management, 3(1), 28-36.

Fama, E. (1981). Stock returns, real activity, inflation and money. The American Economic Review, 71 (4): 45-65Ibrahim, M., \&Musah, A.(2014). An econometric analysis of the impact of macroeconomic fundamentals on stock market returns in Ghana. Research in Applied Economics, 6(2): 47-72.

Granger, C. W. J., \&Newbold, P. (1974).Spurious regression in econometrics. Journal of Econometrics, 2 , 111-120.

Hunjra, A., Muhammad, C., Muhammad, S., Muhammad, F., \& Kamran, K. (2014).The impact of macroeconomic variables on stock prices in Pakistan.Munich Personal RePEc Archive Paper, No. 60791.

Issahaku, H., Ustarz, Y., \&Domanban, P. B. (2013). Macro-economic variables and stock market returns in Ghana: any causal link, Asian Economic and Finance Revue, 3(8), 1044-1062.

Johansen, S. (1988).Statistical analysis of cointegration vectors. Journal of Economic Dynamics and Control, 12, 231-254.

Khan, W. A. et al. (2014). Impact of macroeconomics variable on the stock market index: a study from Pakistan. International Journal of Accounting and Financial Reporting, 4(2), 251-258

Maysami, R. C. Howe, L. C., \&Hamzah, M. A. (2004). Relationship between macroeconomic variables and stock market indices: cointegration evidence from stock exchange of Singapore's AII-S sector indices. Journal Penurusan, 24 (1), 47-77.

Naik, P. K. (2013). Does stock market respond to economic fundamentals? Time-series analysis from Indian data. Journal of Applied Economics \& Business Research, 3(1), 34-46.

Ochieng, D. E., \&Adhiambo, E. O. (2012). The relationship between macroeconomic variables and stock market performance in Kenya. DBA Africa Management Review, 3(1), 38-49.

Philips, P. C. B. \& Perron, P. (1988).Testing for unit root in time series regression. Biometrika, 75(2), 335346.

Rahman, A. et al. (2009). Macroeconomic determinants of Malaysian stock market. African Journal of Business Management, 3(3), 95-106.

Rashid, A. (200). Macroeconomic variables and stock market performance: testing for dynamic linkages with a known structural break. Saving and Development, XXXII, 1, 77-102.

Shrestha, P. K., \&Subedi, B. R. (2014). Determinants of stock market performance in Nepal. NRB Working Paper Series, NRB-WP-24.

Uddin, M. G. \&Alam, M.M. (2007). The impacts of interest rate on stock market: empirical evidence from Dhaka Stock Exchange. South Asian Journal of Management and Sciences, 1(2), 123-132.

Wongbampo, p. \& Sharma, S. C. (2002). Stock market and macroeconomic fundamental dynamic interactions: ASEAN-5 Countries. Journal of Asian Economics, 13, 27-51.

Xiufang, W. (2010). The relationship between stock market volatility and macroeconomic volatility: evidence from China. International Research Journal of Finance and Economics, 49. 
